\title{
Predicting pregnancy outcomes from homocysteine level: an evidence from a North Indian study
}

\author{
Shaina Chamotra ${ }^{1}$, Kushla Pathania ${ }^{2}$, S. K. Verma ${ }^{2}$, Ankit Chaudhary ${ }^{3 *}$
}

\author{
${ }^{1}$ Department of Health and Family Welfare, Community Health Centre Sullah, Kangra, Himachal Pradesh, India \\ ${ }^{2}$ Department of Obstetrics and Gynecology, Kamla Nehru Hospital, Indira Gandhi Medical College Shimla, Himachal \\ Pradesh, India \\ ${ }^{3}$ Department of Health and Family Welfare, Office of Chief Medical Officer Hamirpur, Himachal Pradesh, India
}

Received: 29 January 2020

Accepted: 29 February 2020

\author{
*Correspondence: \\ Dr. Ankit Chaudhary, \\ E-mail: chaudharysaab13@gmail.com
}

Copyright: (C) the author(s), publisher and licensee Medip Academy. This is an open-access article distributed under the terms of the Creative Commons Attribution Non-Commercial License, which permits unrestricted non-commercial use, distribution, and reproduction in any medium, provided the original work is properly cited.

\begin{abstract}
Background: Hypertensive disorders of pregnancy are a major cause of adverse pregnancy outcomes. Though the etiology of spectrum of vascular disorders of pregnancy is still not understood completely, yet abnormally elevated homocysteine level has been implicated in the causal pathway and pathogenesis. Hyperhomocysteinemia has been significantly associated with increased risk of poor maternal and foetal outcomes in terms of PIH, abruption, IUGR, recurrent pregnancy loss, intrauterine death and prematurity.

Methods: The present prospective study was conducted among 180 pregnant women (57 exposed and 123 non exposed) in Kamla Nehru State Hospital for Mother and Child, IGMC Shimla, Himachal Pradesh with an objective of determining association of abnormally elevated homocysteine level in pregnancy and adverse pregnancy outcomes. Socio-demographic, clinical, biochemical including homocysteine level, laboratory, ultrasonographic parameters and foeto-maternal outcomes of pregnancy of all the participants were documented.

Results: The mean homocysteine level of exposed group $(23.26 \pm 10.77 \mu \mathrm{mol} / \mathrm{L})$ was significantly higher than the unexposed group $(8.99 \pm 2.47 \mu \mathrm{mol} / \mathrm{L})$. Among hyperhomocysteinemic subjects, $10.5 \%$ had abruption, $15.8 \%$ had PRES and $8.7 \%$ PPH which was significantly higher than normal subjects. Similarly, patients with homocysteinemia had significantly higher proportion $(21.3 \%)$ of poor Apgar score, more $(41.9 \%)$ NICU admissions and higher frequency $(4.7 \%)$ of meconium aspiration syndrome.

Conclusions: The present study generates necessary evidence for associating abnormally elevated homocysteine levels with pregnancy related hypertensive ailments and adverse pregnancy outcomes. It further demands the need of robustly designed studies and trials to further explore the phenomenon. Moreover, it emphasizes on a simple and timely intervention like estimating the much-neglected homocysteine levels during pregnancy which can definitely contribute in predicting and preventing adverse perinatal outcomes.
\end{abstract}

Keywords: Abnormal homocysteine, Cohort study, Foeto-maternal outcomes, Pregnancy

\section{INTRODUCTION}

Abnormally raised total homocysteine level during pregnancy is an established risk factor for vascular diseases resembling hypertensive disorders related of pregnancy. ${ }^{1} \quad$ During normal pregnancy homocysteine level gradually decreases with gestational age. In hyperhomocystenemia, homocysteine undergoes autooxidation generating reactive oxygen species which inactivate nitric oxide and thrombomodulin leading to endothelial damage and dysfunction. Furthermore it also interferes with fibrinolytic system adding to pathophysiology of preeclampsia and eclampsia. ${ }^{2}$ Abnormally increased homocysteine level has been 
associated with an increased risk of preeclampsia, intrauterine growth restriction, abruptio placenta, stillbirth, and miscarriage..$^{2-5}$ To further strengthen the evidence, the patients with elevated homocysteine values benefitted from therapies that lower homocysteine levels, in the form of folic acid, vitamin B6 which decreases homocysteine by $25 \%{ }^{6}$

As there is dearth of such studies in the geographical area and considering the paucity of information on this subject, the present study was conducted at Kamla Nehru State Hospital for Mother and Child, Indira Gandhi Medical College, Shimla to ascertain the role of homocysteine in hypertensive disorders of pregnancy and its correlation with adverse pregnancy outcomes in terms of maternal and foetal outcomes. The present study is an extension of an earlier case control study that generated substantial evidence of association between hyperhomocystenemia and vascular disorders of pregnancy. ${ }^{7}$

\section{METHODS}

The study was conducted in the department of obstetrics and gynaecology, Kamla Nehru State Hospital for Mother and child IGMC Shimla among the pregnant women (more than 20 weeks of gestation) attending antenatal clinic. It was an additional step conducted in an earlier case-control study where the cohort of pregnant women with normal and abnormal homocysteine level were followed up till the termination of pregnancy. The study was conducted for a period of 1 year from August 2017 through July 2018.

A homocysteine value of $\geq 15 \mu \mathrm{mol} / \mathrm{L}$ was agreed upon to label a pregnant woman as exposed for hyperhomocystenemia. In total 180 women were included in study; 57 women with abnormal homocysteine level and 123 women with normal level were followed for maternal and foetal outcomes at the termination of pregnancy.

A study proforma was designed to collect the data during the study. Socio-demographic parameters, antenatal history, previous medical and reproductive history, clinical signs and symptoms, laboratory investigations, ultrasonic findings, plan and mode of delivery and maternal/foetal outcomes were recorded on the proforma. On admission detailed obstetric, menstrual, medical, treatment and dietary history were noted. Signs and symptoms were inquired from the patients. General physical examination, systemic and obstetrics examination was done as per protocol.

Venous blood sample $(2 \mathrm{ml})$ was collected in a serum test tube with all aseptic precautions. Serum homocysteine concentration was measured by chemo luminescent enzyme method. All samples were processed in Abbott immunoassay analyser 1000/r.
Maternal and foetal monitoring was done which included NST, BPP and Doppler velocimetry. Subjects who were less than 34 weeks and required termination of pregnancy were given 4 doses of dexamethasone. Plan and mode of delivery was decided accordingly. Labour was managed partographically. Details of mode of delivery and any intrapartum or postpartum complication was also recorded. All the patients were followed in postpartum period for any maternal morbidity and mortality. Maternal morbidities like PRES, abruption, atonic PPH etc. are watched for and recorded appropriately. Neonatal parameters including livebirth/stillbirth, Apgar score at 1 and 5 minutes, birth weight, sign of meconium aspiration, admission in NICU were recorded. The feto-maternal outcomes in both groups were compared.

\section{Ethical considerations}

Prior permission was taken from Institute Ethical Committee to go ahead with the study. Personal identifiers were omitted in order to maintain confidentiality and anonymity. An informed consent was taken from the patient and the guardian before including in the study. Potential harms and benefits were explained to the patient before taking consent. Patient was free to leave the study at any point of time and this didn't affect her clinical care. No financial expenditure was incurred by the patient for the sake of study.

\section{Statistical analysis}

Data were entered into Microsoft excel spreadsheet, cleaned and transferred to Epi Info version 7.2.2.6 software for analysis. Continuous variables (homocysteine levels) were presented in the form of mean scores \pm standard deviations. Discrete variables (Socio demographic, biochemical and hematological parameters) were presented in percentages and proportions of each. Pearson's Chi-squared or Fisher Exact test was used to test the statistical significance of dichotomous and categorical data. Mean homocysteine levels of two groups were compared using Independent t-test. Relative risk with $95 \%$ confidence intervals were also calculated to find out the strength of association between exposure and outcome variable wherever required. $\mathrm{p}$ value $<0.05$ was considered as statistically significant. Two-tailed significance tests were used for all analysis.

\section{RESULTS}

A total of 180 antenatal women at period of gestation more than 20 weeks were registered during study period. Exposed group consisted of 57 antenatal women (homocysteine $\geq 15 \mu \mathrm{mol} / \mathrm{L}$ ) while unexposed group consisted of 123 women (homocysteine $<15 \mu \mathrm{mol} / \mathrm{L}$ ). The mean age of exposed and unexposed group was $23.8 \pm 2.3$ and $25.1 \pm 3.2$ years respectively; however, there was no statistically significant difference between the two indicating comparability between the groups. Figure 1 
shows the distribution of study participants as per level of serum homocysteine. About $32 \%$ participants had deranged homocysteine level. The mean homocysteine level in exposed and unexposed groups was $23.26 \pm 10.77$ $\mu \mathrm{mol} / \mathrm{L}$ and $8.99 \pm 2.47 \mu \mathrm{mol} / \mathrm{L}$ respectively; the difference being statistically significant $(\mathrm{p}<0.001)$.

Domocysteine $<15 \mu \mathrm{mol} / \mathrm{L} \quad \square$ Homocysteine $\geq 15 \mu \mathrm{mol} / \mathrm{L}$

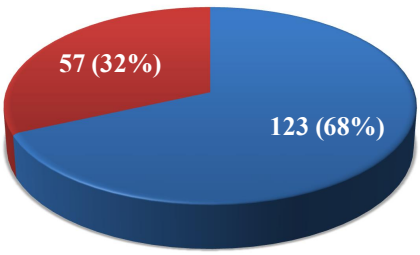

Figure 1: Distribution of study participants according to homocysteine level.

Table 1 shows the association of homocysteine level and maternal outcomes among study subjects. It was observed, in subjects with homocysteine level more than
$15 \mu \mathrm{mol} / \mathrm{L}, 10.5 \%$ had abruption, $15.8 \%$ had posterior reversible encephalopathy syndrome (PRES) and 8.7\% had post-partum hemorrhage $(\mathrm{PPH})$ whereas in subjects with homocysteine $<15 \mu \mathrm{mol} / \mathrm{L}, 54.1 \%$ had abruption, $3.3 \%$ had PRES and $2.4 \%$ had PPH. This difference was found to be statistically significant.

Table 2 highlights the relation of homocysteine and various foetal outcomes among subjects. Among subjects with abnormal maternal homocysteine level, 33.3\% had preterm deliveries while among subjects with normal maternal homocysteine levels $15.4 \%$ had preterm deliveries. The mean homocysteine level in mothers at term pregnancy was $12.49 \pm 8.40 \mu \mathrm{mol} / \mathrm{L}$. The mean homocysteine at preterm was $17.28 \pm 11.50 \mu \mathrm{mol} / \mathrm{L}$. These differences were found to be statistically significant. Among subjects with homocysteinemia, 31.6\% had caesarean delivery while among normal patients $22 \%$ had caesarean delivery; however, this difference was statistically insignificant. Subjects with abnormally raised homocysteine, had significantly higher proportion $(50.9 \%)$ of low birth weight babies as compared to patients with normal level (16.3\%). Although the exposed group had higher proportion $(24.6 \%)$ of still birth than the unexposed group (13\%), the difference was not statistically significant.

Table 1: Relation of homocysteine with maternal outcome.

\begin{tabular}{|l|l|l|l|l|l|}
\hline Homocysteine level $(\boldsymbol{\mu m o l} / \mathrm{L})$ & Normal $(\mathbf{n}=\mathbf{1 5 4})$ & Abruption $(\mathbf{n}=11)$ & PRES $(\mathbf{n}=\mathbf{8})$ & PPH $(\mathbf{n}=7)$ & $\mathbf{p}$ value \\
\hline$>15 \mu \mathrm{mol} / \mathrm{L}(\mathrm{n}=57)$ & $42(73.7 \%)$ & $6(10.5 \%)$ & $5(15.8 \%)$ & $4(8.7 \%)$ & $0.002^{*}$ \\
\hline$<15 \mu \mathrm{mol} / \mathrm{L}(\mathrm{n}=123)$ & $112(92.7 \%)$ & $5(4.1 \%)$ & $3(3.3 \%)$ & $3(2.4 \%)$ & \\
\hline Mean homocysteine level & $13.07 \pm 9.18$ & $15.36 \pm 7.85$ & $17.12 \pm 11.24$ & $16.04 \pm 6.43$ & 0.248 \\
\hline
\end{tabular}

Table 2: Relation of homocysteine with foetal outcome.

\begin{tabular}{|c|c|c|c|c|c|}
\hline Homocysteine level ( $\mu \mathrm{mol} / \mathrm{L})$ & Characteristic & $\begin{array}{l}\text { Preterm } \\
(\mathrm{n}=\mathbf{3 8})\end{array}$ & $\begin{array}{l}\text { Term } \\
(n=142)\end{array}$ & p value & $\begin{array}{l}\text { Risk ratio } \\
(95 \% \mathrm{CI})\end{array}$ \\
\hline$\geq 15 \mu \mathrm{mol} / \mathrm{L}(\mathrm{n}=57)$ & \multirow{3}{*}{$\begin{array}{l}\text { POG at } \\
\text { delivery }\end{array}$} & $19(33.3 \%)$ & $38(66.7 \%)$ & \multirow{2}{*}{$0.011 *$} & \multirow{2}{*}{$2.15(1.24-3.75)$} \\
\hline$<15 \mu \mathrm{mol}(\mathrm{n}=123)$ & & $19(15.4 \%)$ & $104(84.6 \%)$ & & \\
\hline Mean homocysteine level & & $17.28 \pm 11.50$ & $12.49 \pm 8.40$ & $0.004 *$ & - \\
\hline Homocysteine level $(\mu \mathrm{mol} / \mathrm{L})$ & \multirow{4}{*}{$\begin{array}{l}\text { Mode of } \\
\text { delivery }\end{array}$} & $\begin{array}{l}\text { Caesarean } \\
(\mathrm{n}=45)\end{array}$ & $\begin{array}{l}\text { Vaginal } \\
(\mathrm{n}=135)\end{array}$ & \multirow{3}{*}{0.229} & \multirow{3}{*}{$1.44(0.87-2.39)$} \\
\hline$\geq 15 \mu \mathrm{mol} / \mathrm{L}(\mathrm{n}=57)$ & & $18(31.6 \%)$ & $39(68.4 \%)$ & & \\
\hline$<15 \mu \mathrm{mol} / \mathrm{L}(\mathrm{n}=123)$ & & $27(22 \%)$ & $96(78 \%)$ & & \\
\hline Mean homocysteine level & & $13.76 \pm 9.75$ & $12.75 \pm 6.53$ & 0.526 & - \\
\hline Homocysteine levels $(\mu \mathrm{mol} / \mathrm{L})$ & \multirow{4}{*}{ Birth weight } & $\begin{array}{l}<2.5 \mathrm{~kg} \\
(\mathrm{n}=49)\end{array}$ & $\begin{array}{l}>2.5 \mathrm{~kg} \\
(\mathrm{n}=131)\end{array}$ & \multirow{3}{*}{$<0.001^{*}$} & \multirow{3}{*}{$3.12(1.94-5.03)$} \\
\hline$\geq 15 \mu \mathrm{mol} / \mathrm{L} \mathrm{n}=57(\%)$ & & $29(50.9 \%)$ & $28(49.1 \%)$ & & \\
\hline$<15 \mu \mathrm{mol} / \mathrm{L} \mathrm{n}=123(\%)$ & & $20(16.3 \%)$ & $103(83.7 \%)$ & & \\
\hline Mean homocysteine level & & $15.13 \pm 11.32$ & $11.79 \pm 7.64$ & $<0.01 *$ & - \\
\hline Homocysteine levels $(\mu \mathrm{mol} / \mathrm{L})$ & \multirow{4}{*}{ Viability } & $\begin{array}{l}\text { Stillbirth/IUD } \\
(\mathrm{n}=30)\end{array}$ & $\begin{array}{l}\text { Live birth } \\
(\mathrm{n}=150)\end{array}$ & \multirow{3}{*}{0.085} & \multirow{3}{*}{$1.89(0.99-3.59)$} \\
\hline$>15 \mu \mathrm{mol} / \mathrm{L}(\mathrm{n}=57)$ & & $14(24.6 \%)$ & $43(75.4 \%)$ & & \\
\hline$<15 \mu \mathrm{mol} / \mathrm{L}(\mathrm{n}=123)$ & & $16(13 \%)$ & $107(87 \%)$ & & \\
\hline Mean homocysteine level & & $15.51 \pm 9.83$ & $13.10 \pm 9.06$ & 0.919 & - \\
\hline
\end{tabular}


Table 3: Relation of homocysteine with foetal outcomes among live births.

\begin{tabular}{|c|c|c|c|c|c|}
\hline Homocysteine level $(\mu \mathrm{mol} / \mathrm{L}$ & Characteristic & $\begin{array}{l}\text { Apgar }>7 \\
(\mathrm{n}=131)\end{array}$ & $\begin{array}{l}\text { Apgar }<7 \\
(\mathrm{n}=19)\end{array}$ & p value & $\begin{array}{l}\text { Risk ratio }(95 \% \\
\text { CI) }\end{array}$ \\
\hline$\geq 15 \mu \mathrm{mol} / \mathrm{L}(\mathrm{n}=43)$ & \multirow{2}{*}{ Apgar at $1 \mathrm{~min}$} & $30(69.7 \%)$ & $13(21.3 \%)$ & \multirow{2}{*}{$<0.01 *$} & \multirow{2}{*}{$0.74(0.60-0.91)$} \\
\hline$<15 \mu \mathrm{mol} / \mathrm{L}(\mathrm{n}=107)$ & & $101(93.4 \%)$ & $6(6.6 \%)$ & & \\
\hline Homocysteine level $(\mu \mathrm{mol} / \mathrm{L})$ & \multirow{3}{*}{$\begin{array}{l}\text { NICU } \\
\text { admission }\end{array}$} & $\begin{array}{l}\text { NICU } \\
\text { admission }\end{array}$ & $\begin{array}{l}\text { No NICU } \\
\text { admission }\end{array}$ & \multirow{3}{*}{$<0.001^{*}$} & \multirow{3}{*}{$3.45(1.86-6.40)$} \\
\hline$\geq 15 \mu \mathrm{mol} / \mathrm{L}(\mathrm{n}=43)$ & & $18(41.9 \%)$ & $25(58.1 \%)$ & & \\
\hline$<15 \mu \mathrm{mol} / \mathrm{L}(\mathrm{n}=107)$ & & $13(12.1 \%)$ & $94(87.9 \%)$ & & \\
\hline Homocysteine levels $(\mu \mathrm{mol} / \mathrm{l})$ & \multirow{3}{*}{$\begin{array}{l}\text { Meconium } \\
\text { aspiration } \\
\text { syndrome }\end{array}$} & $\begin{array}{l}\text { MAS } \\
(\mathrm{n}=5)\end{array}$ & $\begin{array}{l}\text { No MAS } \\
(\mathrm{n}=145)\end{array}$ & \multirow{3}{*}{0.947} & \multirow{3}{*}{$1.66(0.29-9.58)$} \\
\hline$\geq 15 \mu \mathrm{mol} / \mathrm{L}(\mathrm{n}=43)$ & & $2(4.7 \%)$ & $41(95.3 \%)$ & & \\
\hline$<15 \mu \mathrm{mol} / \mathrm{L}(\mathrm{n}=107)$ & & $3(2.8 \%)$ & $104(97.2 \%)$ & & \\
\hline Homocysteine levels $(\mu \mathrm{mol} / \mathrm{L})$ & \multirow{3}{*}{$\begin{array}{l}\text { Neonatal } \\
\text { Sepsis }\end{array}$} & $\begin{array}{l}\text { Neonatal sepsis } \\
(\mathrm{n}=10)\end{array}$ & $\begin{array}{l}\text { No neonatal } \\
\text { sepsis }(n=140)\end{array}$ & \multirow{3}{*}{0.647} & \multirow{3}{*}{$1.66(0.49-5.59)$} \\
\hline$>15 \mu \mathrm{mol} / \mathrm{L}(\mathrm{n}=43)$ & & $4(9.3 \%)$ & $39(90.7 \%)$ & & \\
\hline$<15 \mu \mathrm{mol} / \mathrm{L}(\mathrm{n}=107)$ & & $6(5.6 \%)$ & $101(94.4 \%)$ & & \\
\hline
\end{tabular}

Table 3 shows the relation of homocysteine and various foetal parameters among live births. Among 150 viable births, women with homocysteinemia had significantly higher proportion $(21.3 \%)$ of poor Apgar score than unexposed women $(6.6 \%)$. About $41.9 \%$ neonates of mother with homocysteinemia needed NICU admission whereas only $20.7 \%$ needed NICU admission in the group with normal homocysteine level. This was found to be statistically significant. Meconium aspiration syndrome (MAS) was seen in $4.7 \%$ and $2.8 \%$ of babies whose mother had homocysteine level $>15 \mu \mathrm{mol} / \mathrm{L}$ and $<15 \mu \mathrm{mol} / \mathrm{L}$ respectively; the difference being statistically insignificant. Sepsis developed in $9.3 \%$ neonates whose mother had abnormal homocysteine level as compared to $5.6 \%$ neonates whose mother had normal level. This difference was found to be statistically insignificant.

\section{DISCUSSION}

The present study revealed that antenatal women with abnormally raised homocysteine were significantly more likely to have adverse maternal outcome in terms of abruption, PRES and PPH. This further reinforces the role of homocysteine in causal pathway of the vascular disorders of pregnancy. Vollset et al also concluded similar findings and acknowledged strong association between homocysteine level and pregnancy complications and adverse outcomes. ${ }^{3}$

It was seen that the risk of having preterm delivery in women with hyperhomocysteinemia was almost as twice as compared to women with normal levels. Moreover, the mean homocysteine level was also significantly higher in the exposed group when the preterm were considered. The participants with abnormal homocysteine level were more likely to deliver IUGR and non-viable babies. Similar results were observed in a study conducted in Lucknow where mean homocysteine was higher where outcomes were IUGR and preterms. ${ }^{8}$ Similarly significant differences between two groups were noticed regarding foetal outcomes. Poor Apgar scores and more NICU admissions were seen in abnormal homocysteine group. Study findings were also corroborated by the findings of studies by Mascarenhas et al, Gaiday et al, and Chaudhry et al. ${ }^{9-11}$

Study had few limitations. Firstly, being a time bound study, the sample size was chosen arbitrarily. Furthermore, the study participants were enrolled utilizing convenience sampling method. This might have affected the generalizability of the study results and external validity of the study.

\section{CONCLUSION}

The present study shows that hyperhomocysteinemia is associated with adverse maternal and perinatal outcome. It was associated with abruption, PRES and PPH in the mother. Various fetal and neonatal complications like RDS, jaundice, IUGR, low APGAR score and stillbirths are seen more often in mothers with raised homocysteine levels.

As study had limited power, more robust data from cohort studies or randomised control trials are needed to recommend the estimation of homocysteine as a routine investigation as a part of prenatal screening and in normal pregnancy. As various factors like vitamin B12, B6 and folic acid have already been studied which can check hyperhomocystenemia, focus on such trial is also deemed necessary.

Estimation of homocysteine levels prior to pregnancy may help to predict and prevent further development of vascular disorders and adverse outcomes associated with them, if timely correction of homocysteine level is done. In the current scenario with focus on quality maternal 
care, it is strongly recommended that the antenatal women must undergo the screening for hyperhomocystenemia.

Funding: No funding sources Conflict of interest: None declared

Ethical approval: The study was approved by the Institutional Ethics Committee

\section{REFERENCES}

1. Mignini LE, Latthe PM, Villar J, Kilby MD, Carroli G, Khan KS. Mapping the theories of preeclampsia: the role of homocysteine. Obstet Gynecol. 2005;105:411-25.

2. Hoque MM, Bulbul T, Mahal M, Islam NA, Ferdausi M. Serum homocysteine in preeclampsia and eclampsia. Bangladesh Med Res Counc Bull. 2008;34:16-20.

3. Vollset SE, Refsum H, Irgens LM, Emblem BM, Tverdal A, Gjessing $\mathrm{HK}$, et al. Plasma total homocysteine, pregnancy complications, and adverse pregnancy outcomes: the Hordaland Homocysteine Study. Am J Clin Nutr. 2000;71:962-8.

4. Nelen WL, Blom HJ, Steegers EA, den Heijer M, Thomas CM, Eskes TK. Homocysteine and folate levels as risk factors for recurrent early pregnancy loss. Obstet Gynecol. 2000;95:519-24.

5. Dutta DC. Textbook of Obstetrics. $9^{\text {th }}$ Ed. Jaypee Brothers Medical Publishers; 2015:217-220.

6. Arun M, Gopinath M, Nirmala C. Prevalence of hyperhomocysteinemia among preeclampsia patients. J Med Sci Clin Res. 2017;05(04):21063-9.
7. Pathania K, Verma SK, Chamotra S, Chaudhary A. Can serum homocysteine predict hypertensive disorders of pregnancy?: An evidence from a case control study in a North Indian tertiary health care institution. Int J Reprod Contracept Obstet Gynecol. 2019;8:3117-22.

8. Jaiswal N, Agrawal A, Agrawal S, Das V, Pandey A, Singh R. Correlation of serum homocysteine levels and pregnancy outcome: the dilemma continues. Int $\mathrm{J}$ Reprod Contracept Obstet Gynecol. 2016;5:391-5.

9. Mascarenhas M, Habeebullah S, Sridhar MG, Revisiting the role of first trimester homocysteine as an index of maternal and fetal outcome. J Preg. 2014:2014.

10. Gaiday AN, Tussupkaliyev AB, Bermagambetova SK, Zhumagulova SS, Sarsembayeva LK, Dossimbetova MB, et al. Effect of homocysteine on pregnancy: a systematic review. Chemico-Biological Interact. 2018;293:70-6.

11. Chaudhry SH, Taljaard M, MacFarlane AJ, Gaudet LM, Smith GN, Rodger M, et al. The role of maternal homocysteine concentration in placentamediated complications: findings from the Ottawa and Kingston birth cohort. BMC Preg Childbirth. 2019;19:75.

Cite this article as: Chamotra $\mathrm{S}$, Pathania $\mathrm{K}$, Verma SK, Chaudhary A. Predicting pregnancy outcomes from homocysteine level: an evidence from a North Indian study. Int J Reprod Contracept Obstet Gynecol 2020;9:1498-502. 